\title{
Comentário a \\ “O REVISIONISMO E OS PERIGOS DA MENTIRA DELIBERADA NA PERspectiva de HanNah ArendT"
}

Valéria Cristina Lopes Wilke ${ }^{1}$

Referência do artigo comentado: PASSOS, F. A dos. O revisionismo e os perigos da mentira deliberada na perspectiva de Hannah Arendt. Trans/Form/Açáo: revista de filosofia da Unesp, v. 44, n. 3, p. 115-134, 2021.

$\mathrm{O}$ artigo "O revisionismo e os perigos da mentira deliberada na perspectiva de Hannah Arendt" enquadra-se na discussão contemporânea acerca do trânsito das notícias falsas, as quais têm contribuído para alguns fenômenos a que assistimos hoje, como, por exemplo, a Pós-Verdade, as Bolhas Informacionais (ou Câmaras de Ecos) nas redes sociais digitais, a volta da Extrema-Direita à esfera pública, a crise das democracias. Fábio Passos constrói sua abordagem pelo viés da apreciação do revisionismo histórico, que age por meio da mentida deliberada. A intenção dessa mentira é auferir algum ganho com a construção de fatos ficcionais, sem lastro nos afazeres humanos no campo da história comum, para assim desconstruir a compreensão histórica e modificar a verdade factual relativa a certos eventos, sua memória e sua interpretação. Como Vidal-Naquet observou, em relação ao revisionista Rassinier, como ter consciência da verdade, se o ocorrido é adulterado?

${ }_{1}$ Departamento de Filosofia da Universidade Federal do Estado do Rio de Janeiro (UNIRIO), Rio de Janeiro, RJ - Brasil. (D) https://orcid.org/0000-0002-7951-7621 E-mail: valeria.wilke@unirio.br.

https://doi.org/10.1590/0101-3173.2021.v44n3.13.p147

\section{(i)}


Ao dialogar com o entendimento de Hannah Arendt acerca da construção do "comum", Passos (2021) recorda a importância de não perdermos de vista que o próprio ato de pensar sempre é pensar alguma coisa. Por conseguinte, a investida contra aquilo que foi elaborado e reconhecido socialmente como a matéria factual da realidade e que sustenta as possíveis perspectivas diferentes em relaçáo a ela, tal como pretendido pelo revisionismo, representa, em última instância, também a ofensiva contra a atividade do pensar que necessita de uma matéria-prima a partir da qual se realiza. À vista disso, o autor indica o elemento primordial no qual o revisionismo histórico atua: ao ameaçar os fatos que preservam o mundo comum, ele póe em risco não apenas a memória social da realidade do mundo, mas também a faculdade de pensamento que trabalha para significar os fatos ocorridos.

O pensamento arendtiano fornece elementos que podemos utilizar também na compreensão da circunstância histórica conhecida como PósVerdade, que, por sua vez, se insere no mesmo horizonte histórico onde Passos (2021) situa o Revisionismo Histórico. Hannah Arendt (2009) admitiu, em Verdade e Política, que a verdade factual está associada aos fatos e aos eventos reconhecidos como legitimamente ocorridos devidos aos diferentes testemunhos, os quais, enquanto fatos, são aceitos e compreendidos como comuns, sendo que são eles que fornecem a base para as concordâncias e discordâncias no diálogo. Ela notou também como a verdade factual é frágil e vulnerável às manipulaçóes e falsificaçóes. Como os fatos e o poder se circunscrevem ao mesmo âmbito da realidade, historicamente, os primeiros têm sofrido os assédios das instâncias de poder. Igualmente ela observou que outros assédios podem ocorrer, tal como o dos revisionismos para os quais Passos (2021) chamou atenção. Conforme Arendt, interpretações diferentes de um mesmo acontecimento foram e continuam a ser elaboradas. Entretanto, o perigo e o erro são produzidos, quando a própria matéria factual é tocada, suprimida ou modificada em alguma de suas partes.

A nosso ver, é justamente na quebra do valor da verdade factual que reside o húmus adequado para a emergência da Pós-Verdade e da interferência política do fenômeno das Fake News, entendidas como informaçóes fraudulentas e não meramente falsas. A Pós-Verdade relaciona-se ao contexto no qual os fatos objetivos valem menos do que os apelos emocionais e as crenças pessoais na elaboração da opinião pública. Em consequência, tornase mais fácil para os sujeitos individuais e coletivos manipularem os fatos e os dados, segundo sua vontade, aspecto que torna mais dramática a situação 
no ambiente em que circulam as informaçóes fraudulentas. No panorama atravessado pela Pós-Verdade e pelas Fakes News, constata-se a erosão da confiança nas fontes de registros e narrativas dos fatos e sua transmissão, seja no campo do discurso científico, seja no da imprensa.

Passos (2021) define as notícias falsas como aquelas produzidas com o objetivo de propagar informaçóes mentirosas acerca de assuntos políticos e as considera também como parte do movimento revisionista em curso, o qual, ao operar na construçáo de uma "realidade paralela", adultera o mundo e fraciona a verdade factual. Nesse sentido, analisa tal revisionismo histórico como um dos caminhos possíveis do que pressupóe como a edificação de "políticas de esquecimento".

Ele chama atenção para aspectos do revisionismo histórico presentes em duas frentes revisionistas realçadas no artigo: a tentativa de reconstruir a história dos anos 1933-1945 sem guetos, Holocausto ou destruição de inimigos políticos (como comunistas, cristãos, homossexuais, por exemplo) e outras etnias, como a cigana; e a história brasileira recente dos anos 19641988, sem perseguiçóes políticas, censura, DOPS, tortura. No bojo dessa discussão, realçou como o espaço público, onde se apresenta a pluralidade humana em açóes e palavras, é esvaziado de sua força política.

Ao evocar Hannah Arendt, explica que a verdade factual não pode ser subsumida na verdade racional, justamente por ela fragilmente se alicerçar sobre os testemunhos que o revisionismo histórico quer calar. O artigo nos recorda, como diria Caetano Veloso, como a matéria vida é tão fina, a matéria da memória social, dos fatos comuns, da democracia; e como precisamos estar atentos e fortes, diante dos assaltos dos revisionismos históricos para silenciar testemunhos e as vozes daqueles como Eli Wiesel, mas como as nossas, que também registramos o assassinato político de Marielle Franco e que, por isso, na qualidade de testemunhas históricas desse fato, estamos atentos e fortes às tentativas de subtraírem a verdade do acontecido.

Por fim, saliento que a análise elaborada por Passos (2021) acrescenta o movimento do Revisionismo Histórico a certos aspectos, como Pós-Verdade, Fake News, ascensão da Extrema-Direita e descrédito das democracias, táo importantes para entendermos o Tempo Presente.

Recordando George Orwell, na perda da verdade factual. o Duplipensar e a Novilíngua colocam-se como vislumbres no horizonte. E não seriam imagens desse Duplipensar e dessa Novilingua o que temos recentemente visto 
como negacionismo da verdade factual da inoperância de fármacos como a cloroquina, para o tratamento precoce do SARS-Covid-19, no momento atual do desenvolvimento das pesquisas médico-farmacológicas, ou da esfericidade da Terra? Estejamos, pois, atentos e fortes.

\section{REFERÊNCIAS}

ARENDT, H. Entre o Passado e o Futuro. São Paulo: Perspectiva, 2009.

PASSOS, F. A dos. O revisionismo e os perigos da mentira deliberada na perspectiva de Hannah Arendt. Trans/Form/Açáo: revista de filosofia da Unesp, v. 44, n. 3, p. 115-134, 2021. 